\title{
Comparison of calcite compositions from extrusive carbonatites at Kaiserstuhl, Germany and Calatrava, Spain: implications for mantle carbonate
}

\author{
F. Wall ${ }^{(1,2)}$, G. Rosatelli ${ }^{(3)}$, D. K. Bailey ${ }^{(4)}$, T.E. Jeffries ${ }^{(2)}$, S. Kearns ${ }^{(4)}$, M. Muñoz ${ }^{(5)}$ \\ (1) Camborne School of Mines University of Exeter, Cornwall, UK, ${ }^{(2)}$ Natural History Museum, \\ London, UK, ${ }^{(3)}$ Università G. d'Annunzio, Chieti Scalo, Italy, ${ }^{(4)}$ University of Bristol, Bristol, \\ UK, (5) Universidad Complutense de Madrid, Madrid, Spain (f.wall@exeter.ac.uk / Fax: \\ +44(0)1326371859/ Phone: $+44(0) 1326371831)$
}

Many extrusive carbonatites are now recognised as having been rapidly erupted directly from the mantle. They carry mantle debris, typically occur around maars and may be our most direct 'window' on the carbonate involved in mantle metasomatism. They increase the connection between carbonatites and kimberlites, which are now also widely regarded as driven by volatiles, especially mantle $\mathrm{CO}_{2}$. However, they also tend to be highly permeable and to alter and recrystallize easily. Thus the identification of primary igneous carbonate can be difficult. Nevertheless, it is critical because if it is possible to find pristine compositions, these are likely to be that of the carbonate in the mantle, free of the fractionation and subsolidus alteration ubiquitous in intrusive carbonatites.

The main aims of this study were to determine the trace element carbonate compositions in the pyroclastic carbonatites to establish if igneous calcite is compositionally distinct from low temperature material and to compare the composition of extrusive calcite to that of calcite from mantle xenoliths. Other major hosts for REE in carbonatites and mantle rocks, including apatite, pyrochlore, clinopyroxene and silicate glass were also analysed.

Two contrasting carbonatites were analysed. Kaiserstuhl, Germany is a well-known alkaline and carbonatite complex, which contains extrusive calcite carbonatite lapilli tuffs, intrusive carbonatites and a variety of intrusive and extrusive alkaline silicate rocks. Intrusive carbonatite has been known there for a long time and the more recent discovery of lapilli tuff was key to establishing that carbonate melt droplets can be erupted (Keller, 1981). It is a good example of what geologists are looking for in establising new carbonatite localities.

The second example is a much more recent discovery of carbonatitic maar volcanism associated with nephelinitic and melilitic volcanism at Calatrava, Castilla-La-Mancha, Spain (Bailey et al., 2004). Calatrava is potentially one of the world's largest carbonatitic provinces with over 200 volcanic centres, many containing carbonate coerupted with alkaline silicate rocks and (in contrast to Kaiserstuhl) with mantle debris. Maars are the major vent form and thus the eruption style is similar to kimberlite. No intrusive carbonatite has been found at Calatrava.

Analyses of the calcite and associated minerals were made by Cameca SX 50 electron microprobe and by LA-ICPMS using a Thermo Elemental PlasmaQuad 3 ICPMS coupled to a frequency quintupled $\mathrm{Nd}$ :YAG laser system operating at $213 \mathrm{~nm}$ (New Wave Research). Spatially-resolved analysis is essential to be able to discriminate between multiple generations of carbonate. The EPMA 
analysis positions correspond exactly with the LA-ICPMS analyses. A range of trace elements was analysed including Sr and REE.

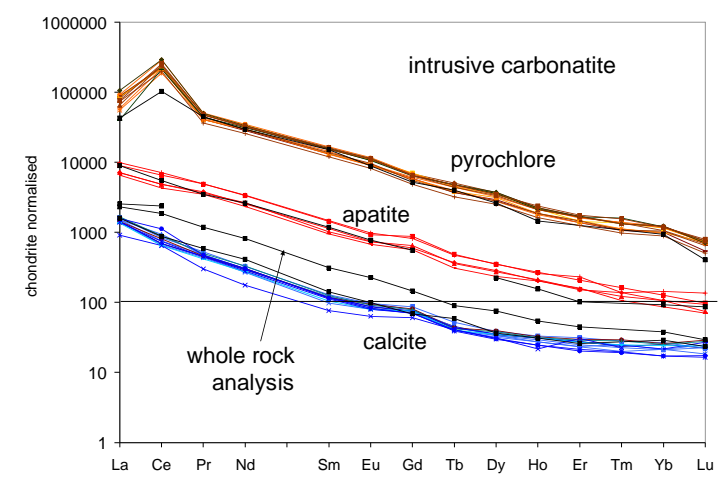

Fig. 1 REE contents of rock forming minerals in intrusive carbonatite, Orberg, Kaiserstuhl, Germany. Black squares are data from Hornig (1988).

\section{Kaiserstuhl}

Two rocks from Kaiserstuhl are featured here: an intrusive calcite carbonatite, for which LAICPMS data could be compared with results from mineral separation and ICPOES analysis (Hornig, 1988) and Henkenberg calcite carbonatite lapilli tuff. Both rocks have similar rock-forming minerals, namely calcite, apatite, and magnetite, with forsterite and pyrochlore in the intrusive. As expected, the REE are concentrated in apatite and pyrochlore (Figs 1 and 2), with REE in the calcite an order of magnitude lower at 200 $2000 \mathrm{ppm}, \mathrm{La} / \mathrm{Yb}$ ratios of $50-140$ and also 0.1 wt\% SrO. The LA-ICPMS results compare well to previous chemical analyses of the coarser grained rock (Fig. 1). There is a marked contrast between sparry calcite that occurs around and within the extrusive lapilli, thought to be the product of alteration of original matrix material and the microcrystalline igneous calcite. The sparry calcite has low Sr, $<0.06 \mathrm{wt} \%$, and low total REE contents, <13 ppm. This result, with higher $\mathrm{REE}$ and $\mathrm{Sr}$ in the igneous material than in later calcite agrees with that generally expected for carbonatites.

The main new result from Kaiserstuhl is that there is a wider range of calcite compositions in the the more rapidly crystallized lapilli tuff than in the intrusive rock (Figs. 1 and 2). Apatite is also more rich in REE and calcite is slightly poorer in REE in the extrusive than in the intrusive rock.

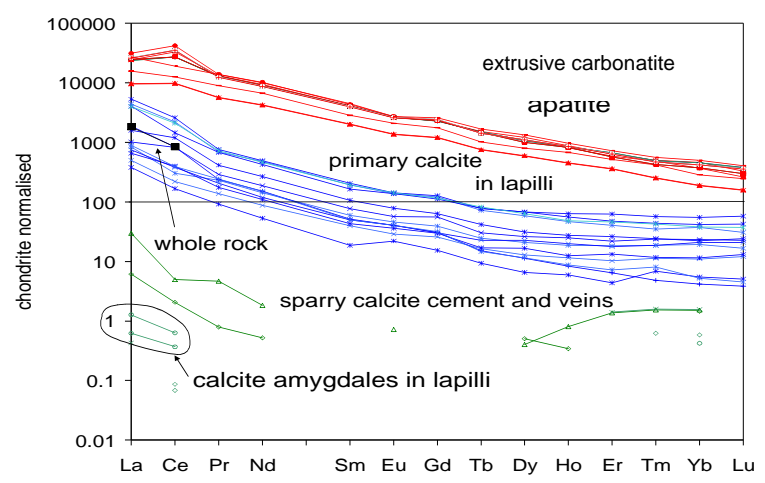

Fig. 2 REE contents of rock forming minerals in extrusive carbonatite, Henkenberg, Kaiserstuhl, Germany.

\section{Calatrava and mantle carbonate}

Eight rocks from Calatrava have been analysed and three are featured here: a scoria cemented by calcite, a calcite carbonatite with globules of calcite and fresh glass, similar to that featured in Bailey et al. (2005) and a lherzolite xenolith that contains calcite associated with small chromite crystals.

The headlines for Calatrava are that, unlike at Kaiserstuhl, apatite is rare and there are few distinct mixed mineral lapilli. Instead the carbonate occurs as globules and micritic matrix material. There is no marked distinction between calcite that is obviously secondary e.g. sparry calcite amongst scoria with 0.3 - 147 ppm total REE, SrO 0.05-0.3 wt\% (Fig. 3) and calcite that texturally appears to be primary igneous material, which has 6 to $1000 \mathrm{ppm}$ total REE (Fig. 4) and $\mathrm{SrO}<0.05$ to $0.6 \mathrm{wt} \%$ and is associated with fresh silicate glasss. Some of the secondary calcite has large negative $\mathrm{Ce}$ anomalies (Fig. 3). Such anomalies are usually caused by oxidation of $\mathrm{Ce}^{3+}$ to $\mathrm{Ce}^{4+}$ in surface environments, and this is a possible discriminator of secondary processes. There are smaller $\mathrm{Ce}$ anomalies in some of the calcite analyses in the globules and xenolith. Calcite in the lherzolite mantle xenolith has a very low trace element content, with 1-70 ppm total REE, Sr 0.02-0.04 wt\% and $\mathrm{La} / \mathrm{Yb}$ 
3-18. So, does this mean that all Calatrava calcite has recrystallized and is secondary? Not necessarily. There are two key comparisons relevant to this dicussion. The first is that coexisting silicate glass and clinopyroxene have higher trace element contents than the calcite (Figs 4 and 5) and this partition is similar to that noted in calcite and foidite glass in mantle xenoliths at Vulture, Italy (Rosatelli et al, 2007).

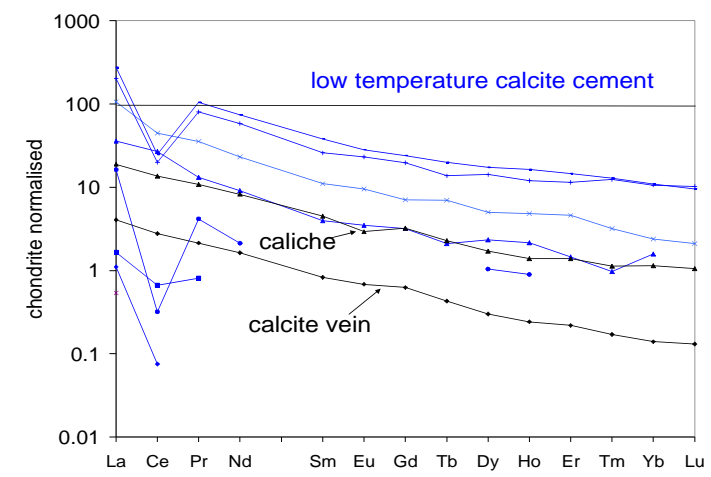

Fig. 3 REE contents of calcite cement in scoria, Calatrava, Spain plus whole rock analyses of a calcite vein and caliche from Calatrava.

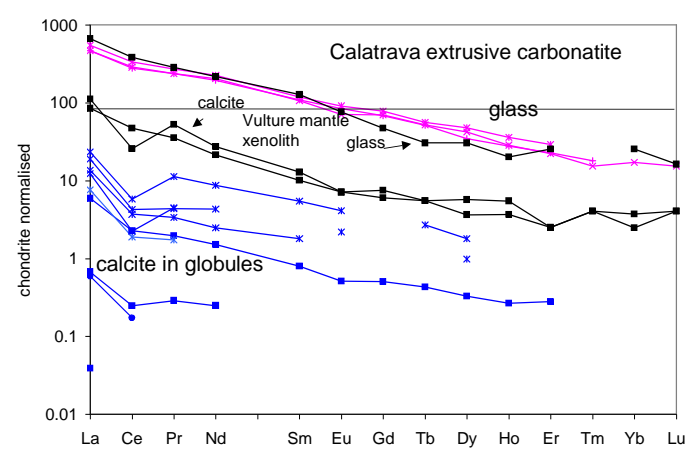

Fig. 4 REE contents of calcite globules and silicate glass in Calatrava extrusive carbonatite (C245B) compared with glass and calcite in a lherzolite xenolith erupted with carbonatitic material from Vulture, Italy.

The second is that the Calatrava igneous calcite falls within the range of calcite analysed in a mantle xenolith from Calatrava and described from a number of mantle xenoliths worldwide and (Fig 5).

\section{Conclusions}

The similarity with calcite from mantle xenoliths leads to the hypothesis that deepsourced mantle carbonate carries low levels of trace elements, with co-existing silicate such as alkaline glass or clinopyroxene as important a host for REE. We predict that other mantle carbonate of deep origin, such as that in kimberlites and carbonate-bearing lamprophyres also has relatively low contents of REE and would like to test this hypothesis.

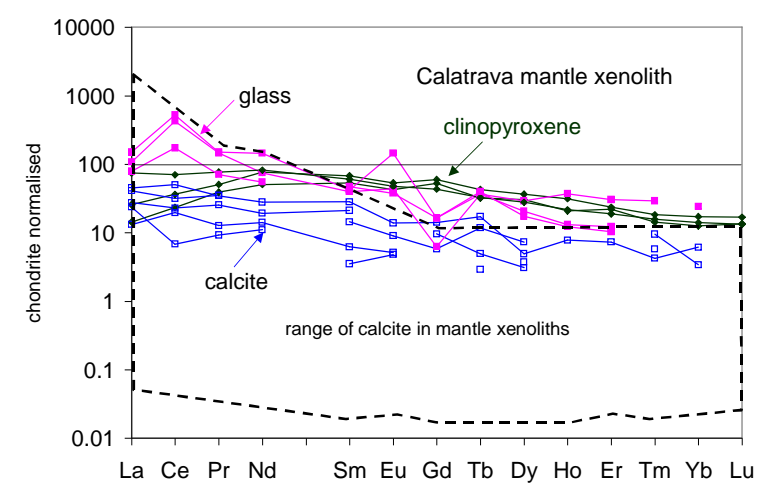

Fig. 5 REE contents in calcite, silicate glass and clinopyroxene in a mantle xenolith from Calatrava, Spain compared with the range of values for calcite in mantle xenoliths reported in the compilation by Rosatelli et al. (2007).

The trace element compositions emphasize the difference between Kaiserstuhl and Calatrava extrusive carbonatites. Kaiserstuhl erupted from a fractionated crustal magma chamber that was crystallizing carbonatite and Calatrava was rapidly and directly transported from the mantle.

\section{References}

Bailey, D.K., Garson, M., Kearns, S., Velasco, A.P. 2005. Newly discorvered carbonate volcanism in Calatrava, central Spain, Mineralogical Magazine, 69, 907-915.

Hornig, I. 1988. Spurenelement-unterssuchungen an Karbonatiten mit hilfe der ICPAtomemissionsspektroskopie, Phd thesis, Freiburg, Germany.

Keller, J. 1981. Carbonatitic volcanism in the Kaiserstuhl alkaline complex: Evidence for highly fluid carbonatitic melts at the earth's surface, Journal of Volcanology and Geothermal research, 9, 423-431.

Rosatelli, G, Wall, F, Stoppa, F, 2007. Calcio-carbonatite melts and metasomatism in the mantle beneath Mt. Vulture (Southern Italy), Lithos, 99, 229-248. 